\title{
Determinants Of Technical Efficiency In Smallholder Corn Crop Farming: Application Of Stochastic Frontier Production Function
}

\author{
Edison \\ Faculty of Agriculture, University of Jambi \\ * Corresponding author: \\ Email: ediedison950@yahoo.co.id
}

\begin{abstract}
.
Agricultural expansion such as corn expansion is often associated with extensification and resulting land acreage loss. Best input practices could increase production and yields and thus potentially reduce land expansion. This study aims to investigate the ability of input, such as land and other factors to affect production in terms of technical efficiency, and investigate the best input practices on corn technical efficiency. Primary and secondary data are used to answer the research objectives. In this study, corn data were used in the 2019 Planting Season. A sample of 120 farmers was taken randomly by applying stratified random sampling that based on land area. Appropriate qualitative and quantitative data analysis methods are used which are distinguished based on their research objectives using the empirical model of production functions, and the technical efficiency model. The results show that all input has an effect to increase corn yield, and support technical efficiency increasing the effect of input using. However, the effect of input using on yields appears to operate through other methods but technical efficiency increases.
\end{abstract}

Keywords: best input practices, corn farming, and technical efficiency

\section{INTRODUCTION}

One of the agricultural commodities that continues to be developed to improve food security is corn. Specifically, corn plants are food plants that are very beneficial to human or animal life. Until now, corn is still a second strategic commodity after rice. From the market side, corn marketing potential continues to increase [1]. This can be seen from the growing needs of corn in Indonesia, which is currently quite large, namely more than 10 million tons of dry shelled annually. The biggest consumption of corn is for animal feed, because as much as $51 \%$ of the raw material for animal feed, especially poultry, is corn. Besides, the role of agriculture in absorbing labor is quite important because the majority of the population in Jambi Province who live in rural areas still do business [2].The problem is quite large, narrow land area, the level of production and productivity of corn fluctuate because the level of soil fertility is quite low and the rain period is quite short [3]. Thus, the level of productivity of corn farming at the national level is still quite low in 2018, such as in Jambi, which is 2.67 tons/hectare [4]. One Region that produces corn in Indonesia is Jambi which is a province that prioritizes economic development in the agricultural sector, especially in the food crops sector. Agricultural commodities, especially the food sector, which contributed significantly to the GRDP of Jambi, especially corn, because most of the area of Jambi is dry land covering an area of 65,972 hectares.

However, Muaro Jambi District has a very important role in producing corn and is very productive to improve the regional economy, with an area of 319 hectares, and yields of 851.73 tons, so the average productivity level is 2.67 tons/ha [4].The development of temporary corn production has been effective for the past few years, it may be relatively difficult to repeat in the future [5]. Production data extracted from the corn crop development program in Jambi Province according to the New Order era (1986-88) and reform (1989-2017) from three typologies of existing cornfields. The various levels of production will reflect the existence of uncertainty and risk factors in corn farming. Also, because the economic crisis and financial difficulties had been resulting in reduced input best practices for corn farming [6]. From this point of view, some experts in agricultural policy are interested in observing the response of supply and demand for inputs to 
corn farmers. Estimates of bid responses such as changes in input use have been reported in several studies $[7,8,9]$. But very few have examined the response inputs concerning technical efficiency.Production data extracted from the corn plant development program in Muaro Jambi Regency of Jambi Province from the typology of existing peatland tends to decrease. The various levels of production will reflect the existence of uncertainty and risk factors in corn farming [1].

With these conditions, agricultural policy experts are eager to evaluate the response of best inputs practices to corn farming. Estimates of bid responses such as changes in input use have been reported in several studies $[8,10]$. However, very few have examined the best input practices concerning technical efficiency.The main problem of Muaro Jambi Regency's corn crop is that the productivity level is still low. The factor causing low productivity is due to the limited ability of farmers to allocate inputs in the form of seeds, fertilizers, peatland, and appropriate pesticide [1]. The low level of productivity is thought to be caused by input best practices which tend to vary every year, especially the rising prices of chemical fertilizers and the prices of pesticides [1]. The issue of technical efficiency is a very important issue to find out about increasing productivity, due to limited input and the lack of opportunities in developing good technology adoption $[9,11,12]$. To improve the level of corn productivity through a combination of the inputs best practices, and the level of plant technical efficiency can increase income. So an increase in the level of technical efficiency can be obtained by improving the level of management capability of farmers. So the problem in this research can be formulated as follows:

(1). What inputs can affect the level of productivity of corn farming?

(2). Is the use of corn farming inputs good and what inputs can affect the level of technical efficiency?

\section{LITERATURE REVIEW}

The Production Function is concerned to input allocation and the level of yield it produced [13]. The purpose of input allocation is to maximize the amount of output with a certain number of inputs used. The production function is concerned to function that explained the mathematical relationship between the inputs used to produce a certain level of output [14]. The production function can be explained as follows:

$\mathrm{q}=\mathrm{f}(\mathrm{K}, \mathrm{L}, \mathrm{M}, \ldots$.

Where $\mathrm{q}$ is the output of certain goods during a period, $\mathrm{K}$ is the capital input used during that period, $\mathrm{L}$ is the labor input in hours, $\mathrm{M}$ is the raw material input used, and others.Equation (1) can be explained that the amount of output depends on a combination of the use of capital, labor, and raw materials. The more precise the input combination, the more likely the output can be produced optimally. [14] states that the production process at the level of corn farming generally follows a Cobb-Douglas function relationship pattern. The Cobb-Douglas function has several advantages, including (1).

Relatively easy and simple compared to other production functions because it can be transformed into a simple linear form, (2). The coefficient of rank also shows the optimum amount of elasticity of production from the use of factors of production, and (3). The estimated elasticity of each factor of production is the product used in the process of estimating the business scale (return to scale) of the factors of production used in the ongoing production process. Weaknesses of the Cobb-Douglas function as an analysis tool, namely (1). Incorrect specification of the variable will produce a negative production elasticity or the value is too big or too small, (2). Error measurement of this variable lies in the validity of the data, whether the data used is correct, too extreme to the top, or vice versa. This measurement error will cause the amount of elasticity to be either too high or too low. In practice, management is an important factor in increasing production, but this variable is sometimes difficult to measure and use as an independent variable in the use of the Cobb- Douglas function [14].

\section{Technical Efficiency Model}

In research, technical efficiency analysis $[15,16]$ can be applied through the use of the following equation:

$\mathrm{TEi}=\mathrm{E}[\exp (-\mathrm{Ui}) / \mathrm{ei}] \mathrm{i}=1,2,3, \ldots . . \mathrm{N}$

Where TEi is the i-producer's technical efficiency, Exp (- E [Ui $\mid$ ei]) is the expected value (mean) of ui using 
the terms $\sum \mathrm{i}$, so $0 \leq \mathrm{TE} \leq 1$. The value of technical efficiency is related to the opposite of the effect of technical inefficiency can also be applied to functions that have the amount of output from a particular input (cross-section data). Producer technical efficiency values are classified as efficient enough if they have a value $>0.7$ and are not yet classified efficiently if they have a value $\leq 0.7$.[17] concerned that the theory of production efficiency is an advanced theory of the theory of basic economics which uses limited input to be able to obtain the highest output or obtain a certain level of output by using the smallest possible cost. Production efficiency is the relative magnitude of the ability of business activities when applying inputs to obtain certain inputs at the technological level [18]. If the above rules are applied to agricultural production activities, farmers try to produce a position of efficiency in applying best practice inputs [19]. If farmers do not apply inputs efficiently, there can be potential that has not been used optimally to improve agricultural profits and obtain a surplus. Conversely, if farmers apply inputs efficiently, additional contributions to agriculture can only be generated by exploration efforts taking into account the growth in these fields [20].

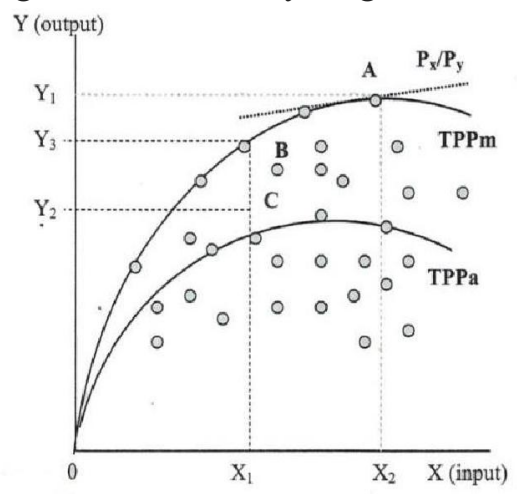

Fig 1. Frontier Production Function

$[15,21]$ illustrate the three types of efficiency in figure 1 . above. The TPPm curve shows the maximum possible output as $\mathrm{x}$ increases, which also shows the production frontier function (Frontier production function), and the TPPa shows the average product that is usually estimated using the Ordinary Least Squared (OLS) technique. Each input that succeeds in producing output is right on the TPPm production curve (Maximum output) then the amount of input usage referred to as production activities reach maximum output while the output achieved under the TPPm curve is expressed as technical inefficiency. The criterion for profit maximization in society will be fulfilled at the optimum production level of the input, for example on the use of inputs at the Xi level and produces an output amount of $\mathrm{Y} 1$, at point A. At point $\mathrm{C}$, any company using input $\mathrm{X} 2$ and producing output $\mathrm{Y} 2$ shows achievements for both efficiencies, technically and allocative. The level of efficiency achieved is Y2 / Y3. In other words, the company that produces Y2 using input $\mathrm{X} 2$ at point $\mathrm{B}$ achieves technical efficiency but is not allocatively efficient. Then the allocative efficiency is $\mathrm{Y} 3 / \mathrm{Y} 1$, while the economic efficiency is $\mathrm{Y} 2 / \mathrm{Y} 1[22,23,24]$.

\section{METHODS}

The study was conducted in Muaro Jambi District because this area is one of the centers of Jambi peatland corn production. Furthermore, Kumpeh Subdistrict was chosen as the location of the study. The location of this research was chosen purposively with the consideration that the location was the corn production center of Muaro Jambi Regency which represented the typology of peatland. This research was conducted in beginning year of 2020.This research was conducted in Kumpeh Subdistrict, Muaro Jambi District by considering that farmers in the sub-district had relatively good productivity in developing corn plants, and could help researchers to obtain primary data. As many as 120 people were chosen randomly using stratified random sampling.

The study uses primary and secondary data. Whereas to see the real conditions, primary data for the 2019 planting season were used from the central villages and the area was determined intentionally (purposive) because of the location, the corn plant center of Kumpeh District, Muaro Jambi District and represented the typology of peatland. The area taken is based on the aspect of corn cultivation which has 
high productivity and an area of peatland that represents large and medium-sized farmers.In estimating empirical models, research uses the Cobb-Douglas production function. According to [25], the function was applied to see the input-output relationship in the Stochastic Frontier function equation and carried out 2 stages, first by using the Ordinary Least Square (OLS) method to estimate the production input coefficient $\beta$. The second is done by applying the Maximum Likelihood Estimation (MLE) method to predict all production parameters $\beta \mathrm{m}$, intercept $\beta 0$, as well as factor variants from both error vi and ui components [26]:

$\mathrm{Y}=\lrcorner 0 \mathrm{X} \quad{ }^{1} \mathrm{X} \quad{ }^{2} \mathrm{X} \quad{ }^{3} \mathrm{X}_{1}{ }^{4} \mathrm{X}_{2}{ }^{5} \mathrm{X}_{3}{ }^{6} e^{v i-u i}$

The study uses the translog function on an empirical model of the production function. $\log Y=\beta_{0}+\beta_{1} \log$ $\mathrm{X} 1+\beta_{2} \log \mathrm{X} 2+\beta_{3} \log \mathrm{X} 3+\beta_{4} \log \mathrm{X} 4+\beta_{5} \log \mathrm{X} 5+$

$\beta_{6} \log \mathrm{X} 6+(\mathrm{vi}-\mathrm{ui})$

Where : variable $\mathrm{Y}$ is corn production $(\mathrm{kg}) ; \mathrm{X} 1$ is land area (ha); $\mathrm{X} 2$ is seed $(\mathrm{kg})$; $\mathrm{X} 3$ is urea fertilizer $(\mathrm{kg})$; $\mathrm{X} 4$ is fertilizer NPK (kg); X5 is pesticides (LTR); X6 is labor (HOK); and $\beta 0$ is intercept; $\beta 1-\beta 6$ is parameter also vi - ui are error terms.

Estimation of the production function uses a particular sample using a two-stage method. Chi-Square is used to estimate the production function. Estimation results obtained from the two-stage method are consistent [22]. To get the level of technical efficiency of corn plants, it can be estimated by applying the equation:

$\mathrm{TEi}=\exp (-\mathrm{E}[\mathrm{Ui} \mid \mathrm{ei}] . \mathrm{i}=1, \ldots, \mathrm{n}$

Where [27]: TE is technical efficiency done by the i-farmer; $\exp (-\mathrm{E}$ [Ui $\mid\lrcorner \mathbf{i}]$ is expected value of Ui with the condition $\llcorner$ I be 0$\lrcorner$ TEi $\llcorner 1$

\section{RESULTS AND DISCUSSION}

Research finding concerning variables that affect the technical efficiency of corn production was extremely exciting and magnificent. Finding from Table 1 explains description and summary statistics for variables including variables, description, averages, standard deviations, and also values of minimum and maximum. These showed that mean output per hectare is around 11 tons, mean land used 2.27 ha, using 20 hours of labour, 101 kilograms of urea fertilizer, 75 kilograms NPK fertilizer, 2.8 liters, and 3 activities extension activity.Production function analysis aims to determine how the use of production inputs such as land area, seeds, fertilizers, pesticides, and labor affects production. How is the production response to the use of production factors? To determine the effect of the use of inputs on production can be seen in Table 2 .

Table 1. Variable descriptions and summary statistics.

\begin{tabular}{|c|c|c|c|c|c|}
\hline Variable & Description & Mean & $\begin{array}{l}\text { Std. } \\
\text { Dev. }\end{array}$ & Min & Max \\
\hline Output Ln(land) & $\begin{array}{l}\text { Total yield per hectare Totalland } \\
\text { used in hectare }\end{array}$ & $\begin{array}{l}10.44 \\
2.27\end{array}$ & $\begin{array}{l}1.09 \\
3.97\end{array}$ & $\begin{array}{l}3.5 \\
0.5\end{array}$ & $\begin{array}{l}24 \\
6.5\end{array}$ \\
\hline $\operatorname{Ln}($ seed $)$ & $\begin{array}{l}\text { Quantity of seed applied by } \\
\text { hectare in kilograms. }\end{array}$ & 34.16 & 2.89 & 10.00 & 16.00 \\
\hline $\operatorname{Ln}($ fertilizer of urea $)$ & $\begin{array}{l}\text { Quantity of fertilizer of urea } \\
\text { applied by hectare in kilograms. }\end{array}$ & 101.27 & 54.92 & 77 & 150 \\
\hline $\operatorname{Ln}($ fertilizer of NPK) & $\begin{array}{l}\text { Quantity of fertilizer of SP36 } \\
\text { applied by hectare in kilograms. }\end{array}$ & 75.22 & 73.04 & 50 & 100 \\
\hline Ln (pesticide) & $\begin{array}{l}\text { Quantity of pesticide } \\
\text { applied by hectare in litre. }\end{array}$ & 2.80 & 1.97 & 1.20 & 4.00 \\
\hline Ln (labour) & $\begin{array}{l}\text { Total of man-hours } \\
\text { per day. }\end{array}$ & 19.8 & 1.83 & 1 & 6 \\
\hline
\end{tabular}

Table 2 shows the value of Adj $\mathrm{R}^{2}=0.8956$, this means that 89.56 percent of the variation in the dependent variable can be explained simultaneously by independent variables such as land area, seeds, fertilizers, pesticides, and labor, while the remaining 10.44 percent is influenced by other factors outside the model. The effect of using production factors simultaneously on the production of maize can be determined using the $\mathrm{F}$ test, and the analysis results obtained by F statistics of 73.54 with a probability of $0.0000<(0.01)$ shows that 
the results have a very significant effect, meaning that the independent variables contained in the model simultaneously had a very significant effect on maize production. The value of $L\lrcorner \mathbf{i}=0.987>1$, this means that the simultaneous use of production factors in area II, which means that each addition to the same input proportion will result in an increasing increase in output, in other words, corn farming is in the production stage of increasing return to scale.

Considering best input practices and technical efficiency estimation it found that a sigma-squared value (0.6231) significant at the $1 \%$ level, indicating a good fit of the model and that the assumption of the compound error term is correct. The gamma $(\gamma)$ value is close to one, meaning that the gap in corn production in the Muaro Jambi is due to technical inefficiency. According to [26] and [27], it means that the random component of the inefficiency effects plays a significant contribution to the analysis of agricultural production. It got information about the availability of the one-sided error factor in the model and therefore, the traditional OLS model is an inadequate representation of the data. The level of mean technical efficiency showing in the research location is $74 \%(0.74)$ meaning that there is a possibility for producers to improve their efficiency by $26 \%$ considering the present inputs and current technology. Data shows that the level minimum of Technical Efficiency between 0.67 and 0.98 . Before evaluating the findings of the inefficiency components, it is good to know that a negative sign on an inefficiency parameter means that the group variable has a positive impact on technical efficiency or a decrease in inefficiency; on the other hand, a positive sign on the inefficiency parameters explains the group variable has impacts technical efficiency negatively.

Table 2. Corn estimation production function

\begin{tabular}{lllll}
\hline Variable & Coefficient & Std Error & t-statistics & Probability \\
\hline Land & 0.201 & 0.039 & 5.154 & 0.000 \\
Seed & 0.083 & 0.111 & 0.748 & 0.613 \\
Fertilizer of Urea & 0.218 & 0.068 & 3.206 & 0.014 \\
Fertilizer of NPK & 0.194 & 0.056 & 3.464 & 0.010 \\
Pesticide & 0.153 & 0.066 & 2.318 & 0.046 \\
Labour & 0.138 & 0.043 & 3.209 & 0.013 \\
Constanta & 102.73 & & & \\
Adj. R-squared & 0.8956 & & & \\
$\Sigma$ squared(v) & 0.0072 & & & \\
$\Sigma$ squared(u) & 0.6231 & & & \\
Mean efficiency & 0.74 & & & \\
\hline
\end{tabular}

\section{Estimation of Corn Farming Production Function}

The frontier productivity function model estimation is used to analyze farm productivity function. The productivity variables are seeds, urea fertilizer, NPK fertilizer, pesticide, labor, and frequency of attending counseling. The results of the estimation of the production function in the study area can be seen in Table 2.Table 2 shows the value of Adj. $\mathrm{R}^{2}=0.8956$, this means that 89.56 percent of the dependent variable (Output) can be explained jointly by the independent variable, while the remaining 10.44 percent is influenced by other factors outside the model.

The productivity elasticity value of the variable land, seeds, urea fertilizer, NPK fertilizer, liquid pesticide, and labor, were $0.201,0.083,0.218,0.194,0.153,0.138$ respectively. If the independent variable is increased by 10 percent with the assumption of ceteris paribus, it can increase the productivity of each by 2.01 percent, 0.83 percent, 2.18 percent, 1.94 percent, 1.53 percent, and 1.38 percent respectively. The value of $L L \mathrm{i}=0.987<1$, which means that the use of production factors is in area II, the stage of the production curve in the area of Decreasing Return to Scale, which means that each addition to the proportion of input will result in an increase in productivity output which is decreasing. Variables that significantly affect the increase in productivity at the level of $\square=0.05$ are land, urea fertilizers, fertilizer NPK, pesticide and labor. While seed variable had no significant effect on productivity. 


\section{Farming Technical Efficiency}

Technical efficiency is a reflection of the farmer's ability to get maximum output from a set of available inputs. In this study, technical efficiency analysis can be measured using the following formula: ET $=\mathrm{E}[\exp (-\mathrm{Ui}) /\llcorner\mathrm{i})] \mathrm{i}=1,2,3, \ldots, \mathrm{N}$. where TEi is the technical efficiency of the $\mathrm{i}$ th farmer. Exp ((-Ui) / \lrcorner i) is the expected value (mean) of Ui provided that _ I becomes $0_{-}$ET _ 1 . The ET value of farmers is said to be quite efficient if it is $>0.7$ and is categorized as inefficient if it is 0,7 . The results of technical efficiency analysis on corn farming in the research area can be seen in Table 2.Table 2 shows that the average level of technical efficiency in maize farming is 0.74 . This shows that the average productivity achieved by corn farmers is around 74 percent of frontier production.

This means that the amount of technical inefficiency is 0.26 (26 percent) or the potential for increased production is still available as much as 26 percent. The results of the analysis of the lowest technical efficiency of farmers were 0.56 and the highest level of efficiency of corn was 0.81 . This shows that the average corn farming in the research location is technically efficient. The results of this study are in line with research by [21] which states that most corn farmers are technically efficient. This can be caused by the use of production inputs that are not in accordance with recommendations. This reflects that the opportunity to increase productivity is quite large because the gap between the maximum level of productivity that can be achieved with the best management system (best practiced) is quite large. This means that to increase farm productivity significantly more advanced innovations are needed that require technological breakthroughs derived from research activities.

\section{CONCLUSIONS}

Research has found the technical efficiency level of corn producers in Muaro Jambi, Indonesia, and explores farm-specific components influencing the efficiency aspect. The data were got from farmers located directly in the interest location of Jambi using a survey method. A Stochastic frontier model was applied to evaluate technical efficiency The best input practices found that the estimation of the coefficients for land, seed, fertilizer of Urea, fertilizer of NPK, labour, were positive. Indicating that if any of these inputs were increased, there may be an increase in crop yields and an increase of returns of capital. The technical efficiency of farmers in the location of interest was $74 \%$. The implication is that technical efficiency in corn production on corn yield could be improved by $74 \%$ through better use of available input and current technology.

\section{REFERENCES}

[1] Edison and Wahyuni, I. Acreage Response Under Price Policy Program on Agricultural Corn Production. International Journal of Scientific and Technology Research. 1(1), Pp. 25-32. 2020.

[2] Anonymous,. Jambi in Number. Board of Planning and Regional Development of Jambi. Jambi. 2020.

[3] Dessale M. Analysis of technical efficiency of small holder wheat-growing farmers of Jamma district, Ethiopia. Agriculture and Food Security 8(1), Pp. 1- 12. 2019.

[4] Badan Pusat Statistik (BPS). Muaro Jambi Statistics. Sengeti. 2020.

[5] Edison, The Responsiveness of Rice Area to Price and Production Cost in Jambi. International Journal of Agricultural System 2(2), Pp. 133-139. 2014.

[6] Edison, Ratnawaty S. dan Nurchaini, D.S. Supply Response of Corn Commodity in Kabupaten Tebo Jambi. Jambi. 2017.

[7] Dewi, R.A.M., Technical Efficiency Analysis of Input Usage on Corn Farming (Case Study Kramat Village, Bangkalan Sub-District, Bangkalan District, Madura). Fakultas Pertanian. Universitas Brawijaya. Malang. 2008.

[8] Guyomard, H., Baudry, M. and Carpenter, A. Estimating Crop Supply Response in the Presence of Farm Programmes: Application to the CAP. European Review of Agricultural Economics 23(1), Pp. 401-420. 2009.

[9] Edison, Economic Efficiency Analysis of Corn Farming in Kecamatan Berbak Kabupaten Tanjab Timur Jambi. Jambi. 2009.

[10] Bahta, Y.T. Jordaan, H. and Sabastian G. Agricultural Management Practices and Factors Affecting Technical Efficiency in Zimbabwe Maize Farming. Agriculture. 10(2), Pp. 1-14 2020. 
[11] Bifarin J.O. Alimi, T. Baruwa, O.I. and Ajeole, O.J. Determinant of Technical, Allocative and Economic Efficiency in Production Industry. Ondo State. Nigeria. 2010.

[12] Fadwiwati A.Y., Hartoyo S, Kuncoro S.U., and Rusastra I.W. Technical Efficiency Analysis, Allocative Efficiency and Economic Efficiency of Corn Farming by Variety in Gorontalo Province. Jurnal Agro Ekonomi. 32(1), Pp. 1- 12. 2013.

[13] Nugroho, B.A. Analysis of Production Function and Efficiency on Corn at Patean District Kendal Regency. Journal of Economics and Policy 8(2), Pp.160-172. 2016.

[14] Soekartawi, Farming Analysis. Universitas Indonesia Press. Jakarta. 2002.

[15] Tasman, A. Efficiency and Productivity Analysis, 1 st Edition. Chandra Pratama. Jakarta. 2008.

[16] Ngeno, V., Mengist, C., Langat, B.K., Nyangweso, P.M., Serem, A. K., and Kipsat, M. Measuring Technical Efficieney among Maize Farmers in Kenya's Bread Basket. Agricultural Journal, 7(2), 106-110.2012.

[17] Nurhapsa. Technical Efficiency Analysis and Risk Behaviour, and its Effect on Hybrid Seed Application on Corn Farming in Kabupaten Enrekang Provinsi Sulawesi Selatan. Tesis.. Program Pasca Sarjana Institut Pertanian Bogor, Bogor. 2013.

[18] Mwangi, T.M. Ndirangu, S.N. and Isaboke, H.N. Technical Efficiency in Tomato Production among Smallholder Farmers in Kirinyaga County, Kenya. African Journal of Agricultural Research 16(5), Pp. 667677. 2020.

[19] Wang, X. and S. Rungsuriyawiboon. Agricultural Efficiency, Technical Change and Productivity in China, Post-CommunistEconomies, 22(2), Pp. 207-227, 2010.

[20] Isaac, O. Technical Efficiency of Maize Poduction in Oyo State. Journal of Economics and International Finance. 3(4), Pp. 211-216 2011.

[21] Ali, I. Huo, X, Khan, I. Ali, H. Baz, K. and Khan, S.U.. Technical Efficiency of Hybrid Maize Growers: A Stochastic Frontier Model Approach. Journal of Integrative Agriculture 18(10), Pp. 2408-2421. 2019.

[22] Anupama J, RP Singh, and R Kumar. Technical Efficiency in Maize Production in Madhya Pradesh : Estimation and Implications. Agricultural Economics Research Review. 18(1), Pp. 305-315. 2005.

[23] Zalkuwi, J.W., Dia, Y. Z., and Dia, R. Z. Analysis of Economic Efficiency of Maize Production in Ganye Local Government Area Adamawa Nigeria. Nassarawa. Report and Opinion. 2(1), Pp 10-16, 2010.

[24] Asmara, R. Fahriyah, and Hanani, F. Technical, Cost and Allocative Efficiency of Rice, Corn, and Soybean Farming in Indonesia : Data Envelopment Analysis Approach. Agricultural Socio-Economics Journal 17(2), Pp. 76-80. 2017.

[25] Oyewo I.O. and Fabiyi Y.L. Productivity of Maize Farmers' in Surulere Local Government Area of Oyo State. International Journal of Agricultural Economics and Rural Development.1(2), Pp. 25-34. 2008.

[26] Battese GE. Frontier Production Function and Technical Efficiency: A Survey of Empirical Applications in Agricultural Economics. Journal of Agricultural Economics 7 (1), Pp. 185-208. 1992.

[27] Coelli T, Rao D.S.P, and Battese G.E. An Introduction to Efficiency and Productivity Analysis. Kluwer Academic Publishers. London. 1998. 